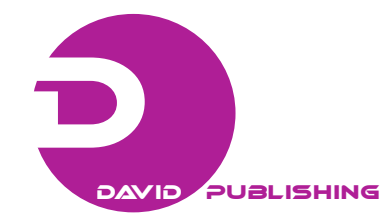

\title{
Redefining Commercial Bus Models in Brazil
}

\author{
Artur Carlos de Morais, Maria Luiza Bastos da Silva e Galindo, Heitor Pereira do Nascimento, Willer Luciano \\ Carvalho, Marcos Fleming Balieiro Alves and Joaquim José Guilherme de Aragão \\ Center of Interdisciplinary Studies in Transportation, University of Brasília, Brasília, Federal District, Brazil
}

\begin{abstract}
Currently, Brazilian buses are divided in three categories: city buses, intercity buses and coaches. That categorization results from the understanding that citizens only need to move around urban perimeters. However, the current bus models available do not fully meet legal demands or cater for all of society's demands. Rural workers and students that live in rural areas also must be conveyed in buses and minibuses. Municipal and state directives prohibit employers to convey them in improper vehicles, such as trucks. Social demands, on the other hand, can be illustrated by federal and state programs that provide vehicles to transport students who dwell in rural settings. Accordingly, this paper proposes a new categorization of bus models available in the Brazilian market, which should account for the unique local operating conditions rural buses face, instead of only considering the type of service they provide. Further, a purpose-built vehicle is suggested in order to cater for the needs of rural workers and students. Rural students represent, in average, five million rural school bus riders.
\end{abstract}

Key words: Bus models, rural matters, rural vehicle category.

\section{Introduction}

The models of buses offered on the Brazilian market currently fall into three categories: city buses, inter-city buses and coaches. The travel needs of the citizen are interpreted according to the geography of the urban perimeters, that is to say the buses offered are either designed to be used in services linking neighborhoods contained within the same city limits or to provide services linking one city to another.

The city model is used for the collective transportation of passengers from one neighborhood to another of a given city on payment of an individual fare. For the collective transportation of passengers from one city to another within the same metropolitan region on payment of an individual fare, there is a specific inter-city service model. The third model that is offered on the market is the highway services model or coach that can be used to transport passengers in inter-city, interstate or international journeys on payment of an

Corresponding authors: Heitor Pereira do Nascimento, M.Sc., research fields: intercity passenger transportation, rural school transportation, transportation technologies. E-mail: hpenasci@ig.com.br. individual fare. This last model is also used in charter services and tourism services, which may be provided inside or outside the city in question.

That current market situation does not fully address all the existing legal and social demands for buses. In terms of the associated legal framework there is an observable tendency for states and municipalities to elaborate legislation that only allows for the use of micro-buses and city buses for the transportation of rural workers and effectively bans the use of trucks for operating that service. There is also a strong social demand for federal and state programs to supply vehicles for the transportation of students and schoolchildren in rural areas. In these two specific cases, the journeys themselves are not restricted to connecting urban areas. In at least one or two points of the trajectory there is a rural nucleus or residential cluster and connecting them may involve the use of unpaved roads with a variety of typologies that constitute obstacles to vehicular traffic.

A survey conducted by Universidade de Brasília at the request of the National Fund for Education Development (FNDE) of the Brazilian Ministry of Education has clearly demonstrated that making use of 
the existing bus models to meet those rural demands has not been able to satisfy the expectations of either service operators or riders. However, it is possible to envisage a product that would be suitable for operating in the rural environment. It would be adapted to the peculiarities of rural surroundings, especially in regard to road infrastructure, and capable of meeting translocation needs whether for the purposes of employment, studying, or leisure, or for social reasons. A collective transport vehicle designed for rural transport services is a necessity and urgently needs to become a reality, offering a new category of vehicle to the market.

This need became evident in the 2006 survey, conducted by the Universidade de Brasília [11-13] from FNDE demand, as well as the market potential unknown until then, and thus neglected by the industry, which offers vehicles for the mass transportation and built for operation on paved roads. This kind of product does not attend a large amount of rural roads in Brazil.

The first step towards making it a reality was taken in the form of a new bus design that resulted from the interaction of the National Education Development Fund of the Brazilian Ministry of Education; the chassis, tire and bodywork manufacturing industries, and the University of Brasília. Certain items were added to existing models and the resulting model has shown itself to be better adapted to the harsh conditions of the rural environment.

Currently, this product is offered to the market specific to the government program (Programa Caminho da Escola), that in three years of the shuttle program has sold approximately 12,000 buses to Brazilian municipalities, in which $23 \%$ were purchased with own funds and the other $77 \%$ with funds from the federal government, serving less than $10 \%$ of students from rural areas of Brazil.

The aim of this paper is to propose a new categorization system for classifying the bus models currently offered on the Brazilian market, based not only on the type of service they are designed to offer, but also taking into account the specificities of the surroundings in which they will be operating and including the category of 'rural vehicle' to meet the needs of workers and students in rural areas, bearing in mind that the latter group consists of approximately 5 million rural school transport users.

A new category, rural, must have the technical specifications for its manufacturing normalized similarly urban bus, by NBR 15570 [4] and its application must be inserted in the Brazilian transit regulatory agency, CONTRAN, establishing a constructive and operational standard.

This paper has eight sections. Following this introduction a research method is presented. The third section presents a legal and market description of buses in Brazil. Next section presents an overview of the unmet demand for buses in Brazil. After that, aspect of rural road infrastructure is presented. The sixth section is intended to briefly report the formation of the Brazilian automobile industry and the presentation of the stages of product developing according to Clark and Fujimoto [17]. The seventh section presents the Brazilian government program (Programa Caminho da Escola) which enabled the development of the suitable vehicle for operation in the rural environment. Finally, the eighth section concludes with general considerations.

\section{Methodology}

The research methodology has been defined into four steps. First a documental search was conducted including the constructive bus standards in Brazil and its legal definitions by regulatory agencies and marketing industry, which resulted in the identification of the supply of models in the domestic market.

In the second step a literature search has been made to understand the development process of automotive products, the characteristics of rural spaces, especially its predominant road infrastructure and respective transportation demand. 
The next step was based on documental search and literature review, in which has been verified the existence of a gap between the legal and market propositions about bus in Brazil, which generate the need for defining a new category of vehicle to attend the rural demand.

In the last step incremental changes in existing categories of buses and its field tests into Brazilian government program (Programa Caminho da Escola) has been defined in conjunction to manufacturers.

\section{Current Supply}

\subsection{The Brazilian Bus}

According to the Brazilian Transport Code, a bus is a collective transport vehicle with the capacity to carry more than twenty people even if in operating conditions it accommodates fewer because of passenger comfort considerations.

The buses now being manufactured in Brazil consist of a body mounted on a chassis which supports the power train, the steering, suspension, electrical and compressed air systems, and the brakes and axles, as shown by Fig. 1. The bodywork is made up of lateral panels, roof and the front and back of the vehicle, with internal furnishings, accessories, and lighting system all of which are supported on the chassis [18]. The chassis is a metallic structure made up of long runners and cross members. Steel alloys are used with properties suitable for use in automotive vehicles such as high mechanical resistance, good conformability and being readily welded [3].

The characteristics of both the body and the chassis vary according to the use the vehicle is designed for.
The variations can be used to classify the various categories of bus that are on the market, as item 3.2 will show.

\subsection{Classification of Buses Produced in Brazil}

The Buses currently produced in Brazil are classified by the regulatory bodies and also by the manufacturing industry itself. Both base their classifications on three basic aspects: application, composition, and dimensions. Application refers to the type of service that the bus is destined to provide, which may be in-city, or inter-city. The term composition refers to whether the vehicle is constructed as a single unit or as a combination of a traction unit and an articulated trailer unit or whether it is built as a double-decker or single-decker. The term dimension is self-explanatory and the dimensions determine the passenger capacity of the model, which may vary from quite small like the category micro-bus to the very largest double-articulated buses.

There are, however, gaps in the classification system adopted by the regulators and the industry. The Brazilian Association of Bus Manufacturers - FABUS classifies buses in the following categories related to services: city, inter-city, coaches, midi-buses, mini-buses and micro-buses. Table 1 shows their classificatory features.

The regulatory classification is the one set out in the Brazilian Transport Code and there is a similar one defined by the Brazilian Technical Norms Association - ABNT. Generally speaking, the two are complementary. The Brazilian Transport Code merely distinguishes buses from micro-buses. In other words,

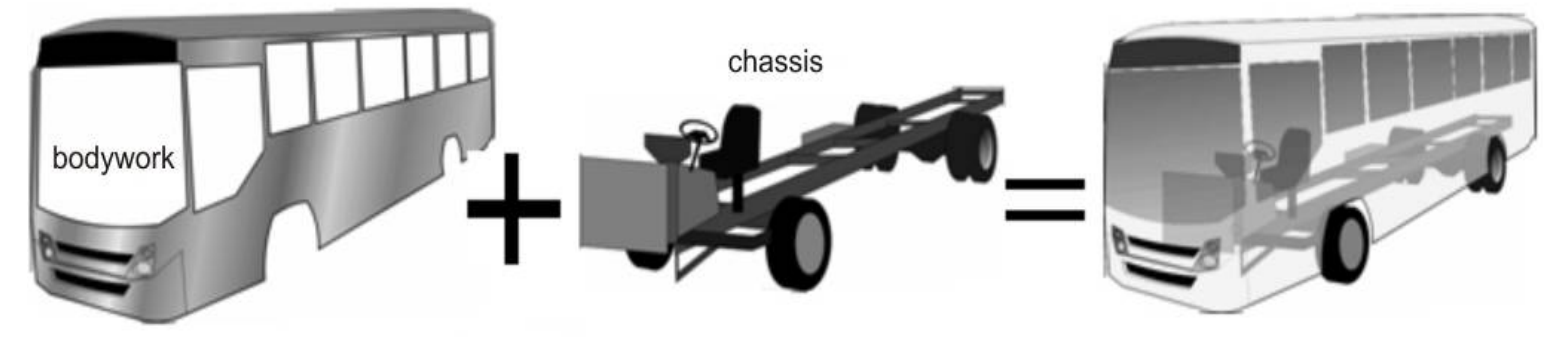

Fig. 1 Chassis and Bodywork. 
the difference between the two is their seating capacity. A bus by that specification is a vehicle designed to carry more than 20 passengers, whereas 20 is the limiting number of passengers for the class of micro-bus according to the Brazilian Transport Code.

The ABNT [4] recognizes and maintains the classification proposed by the Transit Code in regard to the type of bus but subdivides the classification based on composition and dimension. In regard to composition it recognizes the following classes: single-decker, double-decker and articulated buses. The classification according to size establishes the following categories: micro-bus, mini-bus, midi-bus, standard bus, padron, articulated bus and double articulated bus. This last classification is restricted to buses operating in the city environment only. Table 1 sets out the characteristics associated to each of the abovementioned categories.

As mentioned, the classification systems make omissions. Except when it uses composition as the criterion, the ABNT [4] scheme only refers to city buses and leaves out models used on highways. Both ABNT and the FABUS classifications fail to make explicit mention of the rural transport bus which has differences associated to transporting riders in non urbanized areas. In view of the all the gaps and overlapping of the various classification schemes, there is clearly a need for a new classification proposal that

Table 1 Classification of Buses according to the Regulatory Bodies and the Manufacturing Industry. [7, 4, 21]

\begin{tabular}{|c|c|c|c|c|c|c|c|c|c|}
\hline \multicolumn{4}{|c|}{ Categorization } & \multicolumn{6}{|c|}{ Characteristcs } \\
\hline & \multirow[b]{2}{*}{ Contran } & \multirow[b]{2}{*}{ FABUS } & \multirow[b]{2}{*}{ ABNT } & \multirow[b]{2}{*}{$\begin{array}{l}\text { Capacity } \\
\text { (ABNT) }\end{array}$} & \multirow{2}{*}{\begin{tabular}{|l} 
Min. \\
Gross \\
Weight \\
(ABNT) \\
\end{tabular}} & \multicolumn{4}{|l|}{ Dimensions } \\
\hline & & & & & & $\begin{array}{l}\text { Max. Length } \\
\text { (ABNT and } \\
\text { Contran) } \\
\end{array}$ & $\begin{array}{l}\text { Max. Height } \\
(\mathrm{ABNT})^{* * *}\end{array}$ & $\begin{array}{l}\text { Max. Height } \\
(\text { Contran })^{* *} \\
*\end{array}$ & \begin{tabular}{|l|} 
Width \\
$($ ABNT and \\
Contran) \\
\end{tabular} \\
\hline \multirow{7}{*}{ Dimensions } & Micro-bus & \multirow{3}{*}{$\begin{array}{l}\text { Micro-bus } \\
\text { Micro-bus } \\
\text { Micro-bus }\end{array}$} & \multirow{3}{*}{$\begin{array}{l}\text { Micro-bus } \\
\text { Micro-bus } \\
\text { Micro-bus }\end{array}$} & $\begin{array}{l}10-20 \\
\text { pass.* }\end{array}$ & $5 \mathrm{t}$ & $7.4 \mathrm{~m}$ & & \multirow{7}{*}{$4.40 \mathrm{~m}$} & $2.60 \mathrm{~m}$ \\
\hline & \multirow{6}{*}{ Bus } & & & $\begin{array}{l}\text { Min. of } \\
30 \text { pass. } \\
\end{array}$ & $8 \mathrm{t}$ & $9.6 \mathrm{~m}$ & & & $2.60 \mathrm{~m}$ \\
\hline & & & & \begin{tabular}{|l|} 
Min. of \\
40 pass.
\end{tabular} & $10 \mathrm{t}$ & $11.5 \mathrm{~m}$ & & & $2.60 \mathrm{~m}$ \\
\hline & & & \begin{tabular}{|l|}
$\begin{array}{l}\text { Standard } \\
\text { bus }\end{array}$ \\
\end{tabular} & $\begin{array}{l}\text { Min. of } \\
70 \text { pass. } \\
\end{array}$ & $16 \mathrm{t}$ & $14 \mathrm{~m}$ & & & $2.60 \mathrm{~m}$ \\
\hline & & Bus & Padron bus & \begin{tabular}{|l|} 
Min. of \\
80 pass.
\end{tabular} & $16 \mathrm{t}$ & 14 m** & & & $2.60 \mathrm{~m}$ \\
\hline & & \begin{tabular}{|l|}
$\begin{array}{l}\text { Articulated } \\
\text { bus }\end{array}$ \\
\end{tabular} & \begin{tabular}{|l|}
$\begin{array}{l}\text { Articulated } \\
\text { bus }\end{array}$ \\
\end{tabular} & \begin{tabular}{|l} 
Min. of \\
100 pass.
\end{tabular} & $26 \mathrm{t}$ & $18.60 \mathrm{~m}$ & & & $2.60 \mathrm{~m}$ \\
\hline & & \begin{tabular}{|l|}
$\begin{array}{l}\text { Bi-articulat } \\
\text { e bus }\end{array}$ \\
\end{tabular} & $\begin{array}{l}\text { Bi-articulat } \\
\text { ed bus }\end{array}$ & \begin{tabular}{|l} 
Min. of \\
160 pass.
\end{tabular} & $36 \mathrm{t}$ & $30 \mathrm{~m}$ & & & $2.60 \mathrm{~m}$ \\
\hline \multirow{4}{*}{ Aplication } & Urban & Urban & & & & & & & \\
\hline & \multirow{2}{*}{ Coach } & Inter-city & & & & & & & \\
\hline & & Coach & & & & & & & \\
\hline & Scholar & & & & & & & & \\
\hline \multirow{5}{*}{ Composition } & Single deck & & Single deck & & & & $3.80 \mathrm{~m}$ & & \\
\hline & Double deck & & \begin{tabular}{|l|}
$\begin{array}{l}\text { Double } \\
\text { deck }\end{array}$ \\
\end{tabular} & & & & $4.40 \mathrm{~m}$ & & \\
\hline & Articulated & & \multirow{2}{*}{ Articulated } & & & & \multirow{3}{*}{$3.80 \mathrm{~m}$} & & \\
\hline & Bi-articulated & & & & & & & & \\
\hline & $\begin{array}{l}\text { Articulated } \\
\text { trailer }\end{array}$ & & & & & $19.80 \mathrm{~m}^{* * * *}$ & & & \\
\hline
\end{tabular}

Seated passengers only /** Mau reach 15 mif the third axis directional support is installed /*** Maximum height is established by ABNT according the vehicle composition: single deck (unitary or combined) or double deck (one over the other); Contran establishes the maximum height for all categories of bus $/ * * * *$ Contran establishes the maximum length. 
addresses the social and legal aspects of the Brazilian collective transport system and that includes a new category, the rural transport bus.

\section{Demand for Buses in Brazil - Demand Met vs Suppressed Demand}

\subsection{The Brazilian Bus Market}

Brazil is the fourth largest bus manufacturer in the world, surpassed only by China, India and Russia [21]. Fig. 2 displays data on bus production for the domestic market in Brazil.

As the graph clearly demonstrates, there was a drop in bus production that began in 1996 and it only started to increase again in 2004. One reason for that long period of low investment in the activity was the appearance of informal means of transport using small vehicles like vans and micro-buses in the Brazilian cities and that led to a sharp drop in demand for city buses.

The same fact explains the increase in the manufacture of micro-buses in the late 1990s and also the appearance of a new category, the mini-bus, after the year 2000. The gradual suppression of informal carriers in the early 2000s, the tendering processes launched by some Brazilian state capitals and the renewal of the fleets of urban vehicles undertaken by a series of cities led the production of city buses to heat up.

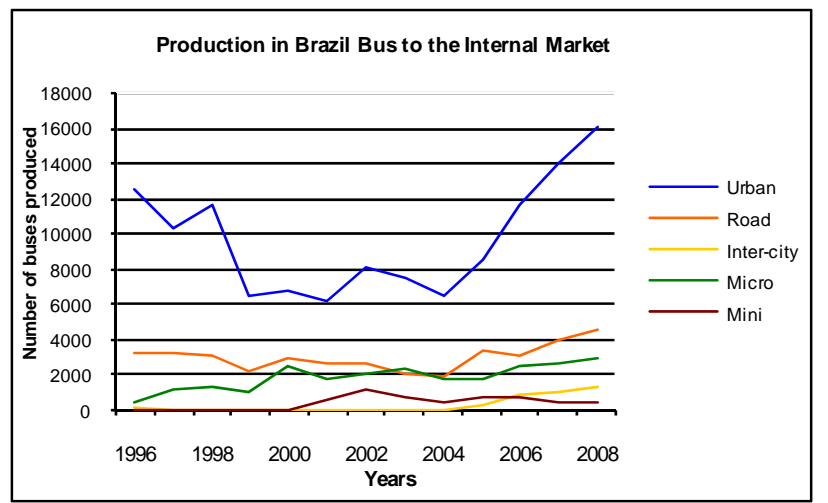

In the inter-city segment, generally represented by road and inter-city modes of passenger transport, production over the same period was fairly free of strong fluctuations. The graph in Fig. 2, illustrating passenger demand for bus transport, also shows the annual passenger demand for interstate road transport services. The data for the years prior to 2005 are not available because prior to that year they were aggregated with the data on semi-urban interstate services, which actually use city bus models. There are also no separate data available on inter-city services.

\subsection{Suppressed Demand - Labour for Rural Production}

To a large extent, Brazil's development has been based on agricultural and livestock production and they continue to be among the country's major economic activities, responding for a considerable proportion of the GNP. Accordingly, there is a great demand for labour from that sector in spite of the extensive mechanization that has taken place in recent years.

Approximately $17 \%$ of all Brazilians engaged in economic activity (over 16,500,000 people) work in rural areas (Table 2) [25]. That fact explains the need for the means to transport those people to their workplaces, usually far from their places of residence, and that is particularly true in the case of temporary, seasonal activities.

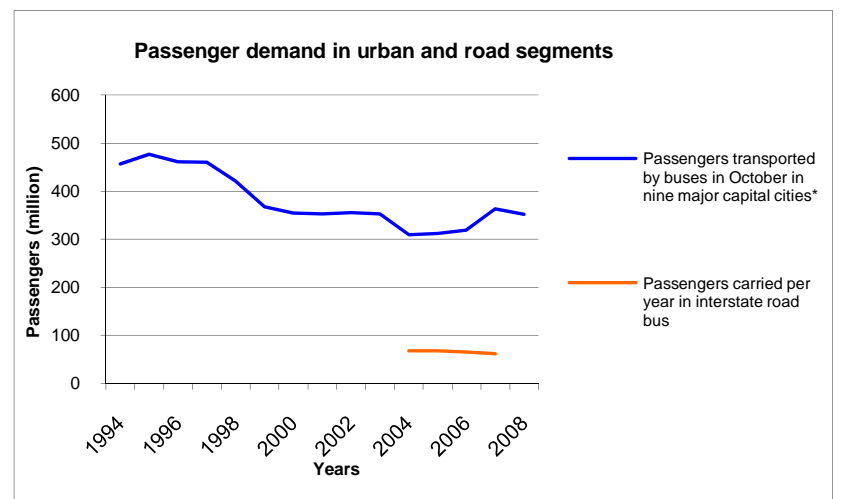

Fig. 2 Bus production and bus passenger transport demand in Brazil [2, 21, 31]. 
Table 2 Number of rural area workers by activity.

\begin{tabular}{|c|c|c|c|c|c|c|}
\hline \multirow{4}{*}{ Selected variables } & \multicolumn{6}{|c|}{ Personnel employed in rural establishments } \\
\hline & \multirow{2}{*}{\multicolumn{2}{|c|}{ Total }} & \multicolumn{4}{|c|}{ Sex } \\
\hline & & & \multicolumn{2}{|l|}{ Men } & \multicolumn{2}{|l|}{ Women } \\
\hline & Total & Age 14 or over & Total & Age 14 or over & Total & Age 14 or over \\
\hline Total & 16567544 & 15505243 & 11515194 & 10919257 & 5052350 & 4585986 \\
\hline \multicolumn{7}{|l|}{ Economic activity groups } \\
\hline Production of non-perennial crops & 6389828 & 5974261 & 4454578 & 4221531 & 1935250 & 1752730 \\
\hline Horticulture and Floriculture & 606564 & 573651 & 403981 & 385695 & 202583 & 187956 \\
\hline Production of perennial crops & 2227656 & 2132142 & 1603720 & 1550184 & 623936 & 581958 \\
\hline $\begin{array}{l}\text { Production of seed, seedlings and other } \\
\text { forms of plant propagation }\end{array}$ & 13488 & 13117 & 10472 & 10272 & 3016 & 2845 \\
\hline Production of livestock and other animals & 6619524 & 6162867 & 4565978 & 4309063 & 2053546 & 1853804 \\
\hline Forest Production - planted forests & 235833 & 221371 & 169518 & 161672 & 66315 & 59699 \\
\hline Forest Production - natural forests & 379020 & 341910 & 240306 & 219691 & 138714 & 122219 \\
\hline Fishing & 48631 & 41447 & 30528 & 26615 & 18103 & 14832 \\
\hline Aquiculture & 47000 & 44477 & 36113 & 34534 & 10887 & 9943 \\
\hline
\end{tabular}

Source: IBGE, Agriculture and Livestock Census 2006.

Presently the transportation of rural workers is highly precarious and carried out by improvised vehicles known as "pau-de-arara" (something like "parrot perches") which are actually trucks with their beds roughly adapted to accommodate rural workers. Such vehicles do not offer adequate safety conditions or any passenger comfort.

\subsection{Rural School Transport: A Brief Description}

In developing countries like Brazil, efforts to ensure that rural residents can have access to full citizenship without leaving the rural areas express themselves in the form of government policies. The present focus of such policies in Brazil is directed at rural school bus transportation, which is considered an important means of guaranteeing that rural communities have access to one of the most basic social services, namely education. Such access is seen as making it feasible for people living in rural areas to improve their basic living conditions.

In that context, Rural School Transport comes to the fore to address the needs of students either living or studying in rural areas and provide them with the necessary means of mobility to pursue their studies.
According to Nascimento et al. [30], Rural School Transport is "the translocation that occurs as a result of the intentions of students residing and/or studying in rural areas and its purpose is to provide such translocation and enable them to study”.

Statistics produced by the Brazilian School Census 2009 show that Brazil has 8,098,191 students in basic education in rural or urban areas that make use of school transport services provided either by state or municipal authorities. 5,115,678 of those students actually reside in rural areas, $38 \%$ of them are in schools run by the state government and $62 \%$ in the municipal schools network. Comparing those numbers with the total number of students that enrolled in Basic Education in that year, which was 52,580,452, students residing in rural areas and requiring school transportation services amount to $10 \%$ of the total.

This kind of transport is currently being provided in an extremely precarious manner using vehicles from the urban environment - usually already old and basically unsuited for the specificities of rural areas and vehicles that are actually designed for transporting cargoes are widely used. 
A national survey carried out by Ceftru [11] gathered data from 2,200 Brazilian municipalities and shows that the average vehicle being used for Rural School Transport purposes is over 15 years old (Fig. 3). It is also important to register that in some parts of the country vehicles were being used that were over 70 years old.

An analysis of the composition of the fleet of vehicles reveals that $22 \%$ are not suitable for transporting passengers and consist of trucks, pick-ups, private cars and motorbikes, among others (Fig. 4).

\section{Legal Aspects of Rural Transportation and Infrastructure}

\subsection{Contextualization of the Rural Environment}

Veiga [36] proposes that the urban/rural relationship expresses itself in three basic types of concrete situations: (1) essentially urban regions metropolitan areas — (2) essentially rural regions almost always remote regions where original ecosystems have been preserved or become the object of conservation - (3) innumerable intermediary regions - extremely heterogeneous, where ecosystems may be partly altered or anthropised to varying degrees as in the case of agglomerations like small residential clusters, small towns and villages.

Thus a dichotomised conception of rural space and urban space whereby the terms can be defined by considering one as the negation of the other is not really useful for constructing a consensual understanding of these two spaces. In the view of Reis [33] it is impossible to understand urban and rural spaces separately from one another because they are realities that cannot exist in separation. The question of defining

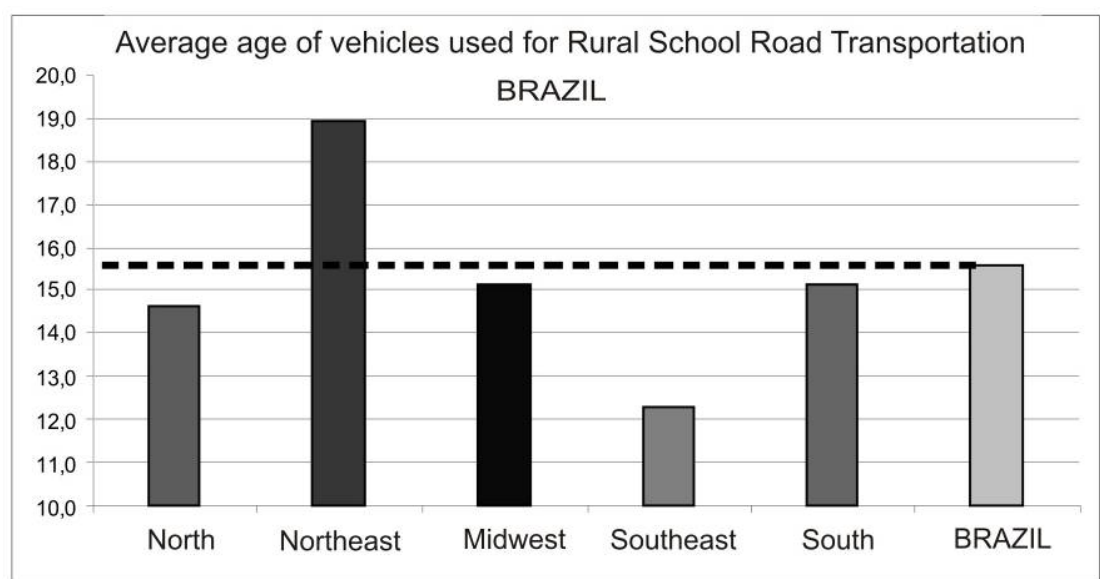

Fig. 3 Average age of vehicles used for Rural School Road Transportation purposes [11].

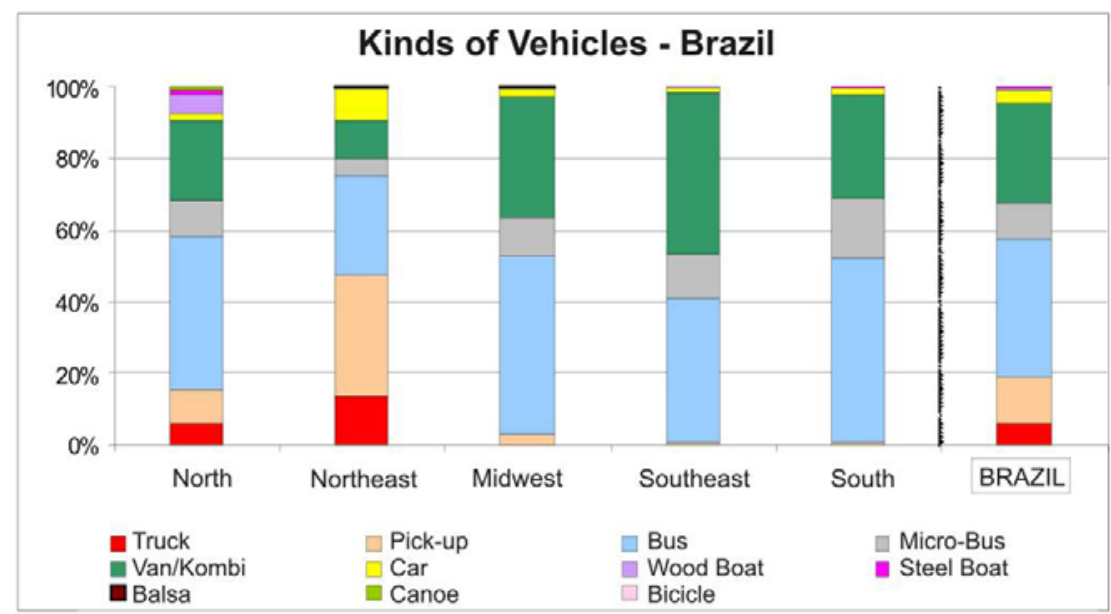

Fig. 4 Composition of the Rural School Transport Fleet by Brazilian Macro-region and by Brazil [11]. 
what is rural and what is urban in Brazil is a discussion that is still far from being settled. That author also states that another idea in circulation regarding urban/rural relationship, the idea of a continuum is also an unsatisfactory translation of the real situation as the word itself suggests a close approximation of the rural space and the urban reality.

International practices regarding the definition of urban space and rural space vary greatly from country to country. The criteria used may be demographic, administrative, or legal criteria or any combination of the three. Countries like Argentina, Mexico, Venezuela, Denmark, Switzerland, Austria, Portugal, Italy, Spain and Ireland use population parameters to differentiate urban from rural areas. Ireland considers agglomerations with over 100 inhabitants as urban whereas in Greece the figure is over 10,000 inhabitants for a space to be classified as urban [5]. In Brazil, however, the criterion for classifying a home as being in a rural or urban area is specifically defined by law and set out in the terms of Decree/Law N 311 dating back to 1938, which delineates Brazil's territorial divisions. The definitions used by the Brazilian Statistics and Geographic Institute - IBGE clearly show the normative nature and origin of the definition of urban and rural spaces in Brazil:

Municipality - Municipalities are autonomous units at the lowest level of the country's political-administrative hierarchy.

City - A place with the same name as the municipality it belongs to and where the respective municipal authority is installed.

District - Administrative sub-units of a municipality.

Town - A place with the same name as the district it belongs to and where the administrative authority of the district is installed excepting the district where the municipal authority is installed.

Urbanised areas of cities or towns - are those areas legally designated as urban and typified by the presence of constructions, street networks and intense human occupation; areas affected by transformations resulting from urban development; and those areas formally allocated and reserved for urban expansion.

Non urbanised areas of cities or towns - are those areas legally designated as urban but typified by occupation of a predominantly rural nature.

Isolated urban areas - Areas designated by municipal law, separated from the site of the installation of the municipal authority or of the district authority by a rural area or bay any other legally constituted boundary.

Rural cluster - a population agglomeration typified by a group of adjacent buildings (separated by 50 metres or less), of a permanent nature and situated in an area legally designated as a rural area.

That classification underscores the convention that all sites where municipal authorities are installed (cities), district authorities are installed (towns) and areas designated as isolated urban areas by the respective Municipal Legislative bodies are considered to be urban areas irrespective of any other geographic structural or functional criteria. That obliges the inhabitants of any municipal administrative centre to consider themselves as urban residents and has led to the absurd situations of indigenous populations and groups of forest surveillance guards living in conservation areas being classified as urban dwellers [36].

This kind of normative approach is reflected in the figure for the percentage of the population living in urban areas: $81.25 \%$ [26], which various authors have contested [1, 5, 36], because, as has been mentioned, no effective consensus has been established as to what is rural and what is urban.

Authors of the scientific literature on transport [11, $22,35]$ tend to accept and use the legal criteria established for defining the various rural and urban spaces of Brazilian municipalities. In regard to the questions of urban transport even when the road network in question is precarious or even non-existent, Ferraz and Torres [22] believe that what really 
determines the technology to be used in operating a transport system is the conditions of the road transport infrastructure. In the case of transport in the rural environment, the predominant structures are paved main roads and secondary local dirt roads.

\subsection{Typical Features of Local Secondary Roads: Extension and Main Defects}

Secondary dirt roads also known as rural roads or "agrovias" are local and usually municipal roads. They may sometimes be surfaced but generally speaking they are not and consist of a single track with a modest road bed and their traffic flows are not intense [28].

These local secondary roads are actually very important in Brazil as they are the starting point for the flux of a variety of products generated in rural areas destined to supply the urban areas or for exportation. In addition to their importance as an economic factor they are also socially important, representing the link between rural communities and services available in the urban milieu like education, health, employment and leisure.

Due to Brazil's tremendous territorial extension, the number of such secondary dirt roads is very high and they have their own characteristics in regard to trafficability. Factors like relief, climate, and type of soil are highly influential in defining the quality of such roadways but the process used to build them and the schemes used to maintain them are also highly relevant.

Such roads are prone to a series of problems that eventually affect trafficability. According to Mariotoni [29], the main problems detected in small unpaved local roads are: the poor support capacity of the road base, the low performance of the road surface, deficiencies in the drainage system, and/or a combination of those factors.

According to Nunes [32], the main problems are:

- Inadequate transverse section;

- Undulations/Corrugations;

- Dust;

- Holes/Potholes;
- Ruts;

- Segregation of the aggregate used;

- Sand patches;

- Erosion;

- Deep mud patches.

The consequences of those factors are that traffic conditions on local dirt roads are usually difficult especially in rainy periods when all the problems are exacerbated. A study conducted by Ceftru [11] clearly reveals the precariousness of conditions in local dirt roads in Brazil. The study visited a set of municipalities and investigated the conditions of the roads used by Rural School Transportation services. It showed that more than $90 \%$ of the roads were unpaved. That was to be expected as all of them were in rural areas. They also presented very poor trafficability levels with little or no maintenance, holes and deep mud patches and other pathologies that made it difficult for vehicles to get to some places at all (Fig. 5). All of that is a source of discomfort for the students, it increases the time of journeys and creates a serious risk of accidents.

Safety in the transportation of students and workers in rural areas of Brazilian municipalities is not only jeopardised by the poor quality of the road infrastructure but also by the quality of the vehicles used to operate it. As often as not they are very old and, having been designed and used for urban service, they are entirely unsuited for rural service as for example: motorbikes, large family cars and especially trucks [11].

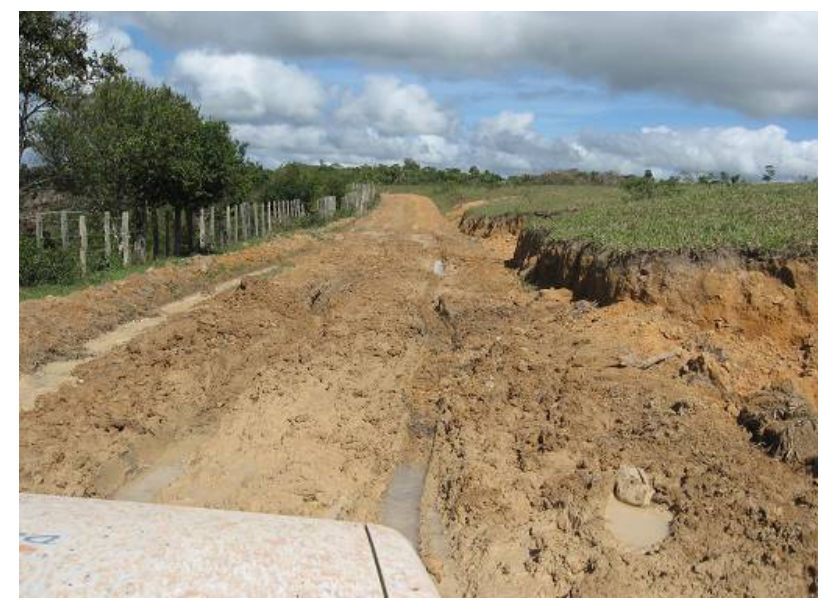

Fig. 5 Example of the kind of roads used by Rural School Transport services. Source: [11] 
To cut down the level of risk in this kind of transport, several Brazilian states are implanting measures to prohibit the transportation of rural workers in any vehicles other than buses or micro-buses.

\section{Product Development in the Brazilian Vehicle Manufacturing Industry}

\subsection{Product Development Theory}

The Brazilian Vehicle Manufacturing Industry consists of a set of companies that both manufacture and assemble a wide variety of automotive vehicles including buses. Innovation occurs most frequently in the production lines of cars and light commercial vehicles. In the other segments changes are less frequent partly because of the nature of the vehicles themselves but also because of market and manufacturing considerations like keeping down the number of suppliers, supply frequency and custom built vehicle production [9]. Product development in this industry is directly conditioned to specific phenomena in the Brazilian scenario such as 1,000 cc. flex-fuel engines, different road and highway conditions; and the properties and local specification of materials used to attend Brazilian safety and pollution regulations $[15,16,19]$.

Consoni \& Carvalho [19] identify a series of studies attempting understand how a product is born, developed and administrated inside the companies and the said studies also seek to describe how optimum performance of those activities can be achieved. Outstanding among those studies is the research conducted in the automotive vehicle manufacturing industry by Clark \& Fujimoto [17] where the authors identify fours stages of the Product Development process: product conception, product planning, product engineering and process engineering. They describe each stage as follows:

Product Conception is the stage at which the consumer's objectives are defined, simulated and analysed and the technological possibilities and economic feasibility are examined. Those elements then have to be conjugated and translated into a description of the product that is to be developed. In short, at this stage an analysis of the possibility of creating a new product is materialised in the form of concept.

Product Planning is the stage at which the development details are harmonised; a link is established between the concept and the actual design of the product. At this stage costs and performance goals are specified, components are chosen and the vehicle design and layout are defined.

Product Engineering seeks to implement the plans drawn up at the previous stages, that is, the details of the projected vehicle are translated into engineering terms. This stage comprises three cycles: design-fabrication - testing (producing the blueprints of each component and system; constructing the respective prototypes and testing them to check conformity with the pre-established performance objectives).

Process Engineering is the stage at which the connection is established between the concept of the product and its actual manufacture; all the accumulated information on the product is converted into information on tooling, equipment, and software needed for production including the qualifications of workers involved in the production process, and the operational protocols to be used in the production stages.

The stages that have been delineated above do not occur in a linear sequence but simultaneously and in an integrated manner (Fig. 6). That overlapping of the various stages is desirable because it reduces the length of time needed to effectively develop the product [20].

\section{A Successful Attempt: The Way to School Program}

\subsection{The Way to School Program}

In 2007, the Federal Government through the Brazilian Ministry of Education launched a Program 
entitled "The Way to School” (Caminho da Escola) with the intention of "renewing the fleet of school transport vehicles, guaranteeing safety and quality in the transportation of students and schoolchildren, contributing towards a reduction in the rate of school drop-out; and expanding access to and permanence in schools for students enrolled in basic education in the rural areas of the state and municipal schools networks."

Other objectives of the Program are to standardize school transport vehicles and reduce their prices by achieving gains in scale in sales, special tax exemptions, and making the procurement and delivery process more transparent by means of direct delivery from the manufacturer to the state or municipal authority purchasing the vehicles without using the traditional means of transferring the amounts involved [24].

At the time this Program was launched the vehicles being produced by industry for school transport services were typically city bus models and did not satisfy the requirements or objectives of the Program "The way to school".

Some technical features that needed to be incorporated to a Rural School Bus model were firmly established. The first version of the model that was produced only satisfied some of the requirements for operating Rural School Transport services because of industrial limitations and the industry itself declared that more time was needed for it to properly develop a rural school transport vehicle. Only a few specific items were incorporated in the 2008 model to adapt it for such operations.

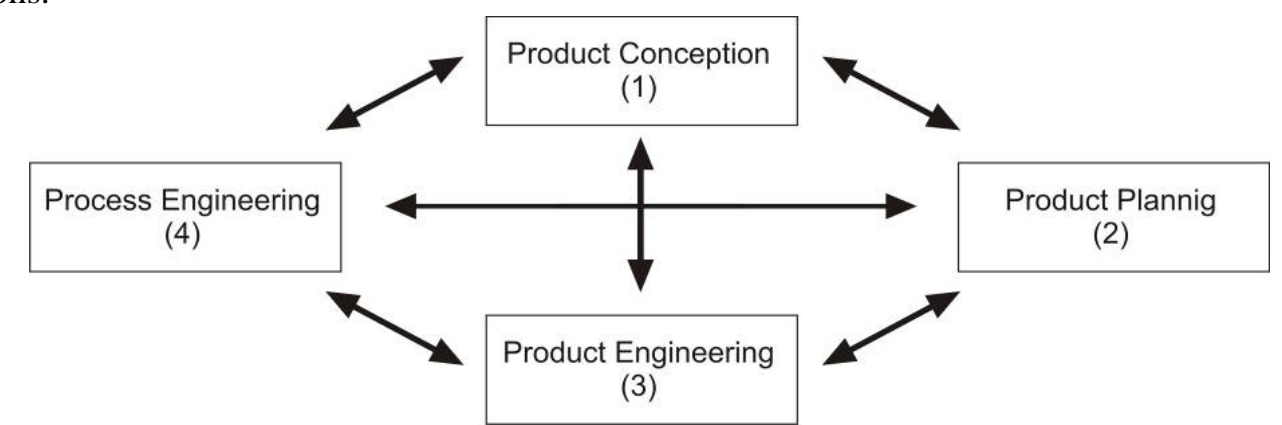

Fig. 6 Integration of the stages in developing products and processes according to Clark and Fujimoto [17, 19].
In the second year of the Program the Rural School Bus Model — ORE 2009 — finally presented all the features recommended for operating rural school transport services. The elements that characterize this new vehicle are firmly anchored in the respective normative legislation (Brazilian Transport Code and specific regulations applicable to vehicles destined for collective passenger transport determined by the National Transit Council - Contran, the National Transit Department — Denatran, the National Environment Council — Conama and the Brazilian Environment Institute - Ibama) in addition to the specifications of the ABNT - Brazilian Technical Norms Association. The alterations also obeyed other criteria like accessibility and resistance to the rough conditions of the terrain to be traversed.

\subsection{The Negotiating Process}

The development of this vehicle required the construction and accumulation of technical knowledge with a certain degree of complexity not only in regard to long-term innovations but also to finding incremental solutions, that is, solutions designed to preserve the traditional manufacturing techniques. This knowledge acquisition process was first delineated at the stage when the concept of the new vehicle was being formed, when Ceftru, FNDE, Inmetro and the manufacturers defined the alterations and established the three major constituents of the ORE 2009: (a) chassis; (b) bodywork and (c) furnishings, accessories and on-board equipment. 
The participation of those entities in the formulation of a new vehicle model in alignment with the demands and specificities of Rural School Transport was achieved by holding public hearings. The specificities of transporting passengers in rural areas were outlined to the entities and bodies involved in the production chain. Up until then the sector had little awareness of those conditions. That lack of knowledge stemmed from the fact that the rural zone had never been a purchaser of new vehicles. Up until 2008 no manufacturer produced vehicles specifically designed to operate in rural areas.

With the appearance of the Program "The Way to School" the manufactures were suddenly faced with a new client for whom they not only had to develop a new product, but would also have to make it feasible to install all the infrastructures for post-sales technical assistance, in view of the inherent weaknesses of the new client.

The success obtained in forming the concept was due to the industrial companies' willingness to recognize the differences in regional demands and preferences and the important distinction between "urban" passenger transport market and the "rural" passenger transport market [19]. In the specific case of the vehicles associated to the Program, that recognition was an important input for the process of developing the products that make up the new Rural School Bus.

\subsection{The Rural School Bus}

The Rural School Bus was specifically conceived for the rural environment. Its structure includes differences in the bodywork (reduction in the height of the lateral skirts) and is characterized by an overall reinforcement that enables it to overcome obstacles that are inherent to rural areas. Also it is endowed with series of items that help to make it suitable for its specific purpose transporting students and schoolchildren in rural areas.

In terms of the normative framework, the starting point for structuring the proposal for a vehicle model for Rural School Transport purposes was ANBT norm
NBR 15570 [4] — Transport: Technical specifications for the manufacture of vehicles with urban characteristics for the collective transportation of passengers - with modifications to address the specificities of the rural environment.

The Rural School Bus 2009 has been classified into two models - conventional and reinforced - and each is offered in 3 sizes. The conceptual model considers it as composed of three main structures: (1) chassis; (2) bodywork; and (3) the set of furnishings, accessories and on-board equipment.

The chassis constituent is composed of seven main elements: (1) the chassis itself; (2) the power train; (3) the steering system; (4) the suspension; (5) the electrical system; (6) the brakes system; and (7) the compressed air system.

The chassis itself has been reinforced by the addition of cross-members and its dimensions, which vary according to the overall size of the vehicle and have been designed to ensure that the minimum angles of attack and departure are suitable for operating on roads in poor conditions (Fig. 7). To that end, the forward and rear overhangs have been reduced and the distance between axles and clearance height has been increased.

The bodywork is composed of two parts - the internal compartment and the external bodywork - and it was also modified. The modifications to the external bodywork are shown in Fig. 8 and consist of:

- Installation of mudguards behind the front and rear wheels;

- Installation of two connections for towing (one in front and the other behind);

- Wrap-around fenders that are curved or angled at their lateral extremities;

- Retractable rear fender with a specified maximum height from the ground of $650 \mathrm{~mm}$. which avoids interfering with the angle of departure;

- Reduced height for the lateral skirts but increased height from the ground;

- Reverse gear light on the back end and a sonic warning device installed at the rear of the vehicle to assist in maneuvering, especially at night. 
- Another important feature that must be noted is that it was determined that the external bodywork must be painted "school-bus yellow" and the color was jointly established by the industry and the FNDE. The choice of color is partly because yellow is a color associated to safety and partly because it makes it possible to immediately recognize a vehicle engaged in transportation of students or schoolchildren anywhere in the country. It was also established that the word "SCHOOL" must also be displayed in large letters on the sides of the bodywork.

The most important alterations to the inner compartment are: (1) a space specifically reserved to safely accommodate at least one wheelchair or a guide dog accompanying a person with visual deficiency; (2) the removal of all rails and other fittings that would provide support for standing passengers, plus (3) narrowing the aisle between the seats to a width of 300 $\mathrm{mm}$ (three hundred millimeters). It should be emphasized that the central aisle is an integral part of the set of furnishings, accessories, and on-board equipment known by the acronym MAE-E in Portuguese.

MAE-E has been defined as the set of furnishings, accessories and on-board equipment that once they have been duly installed in a vehicle, typify its suitability for operating a given type of passenger transport service and endow the service with the qualities of safety, comfort, accessibility and mobility appropriate to the service in question [25].

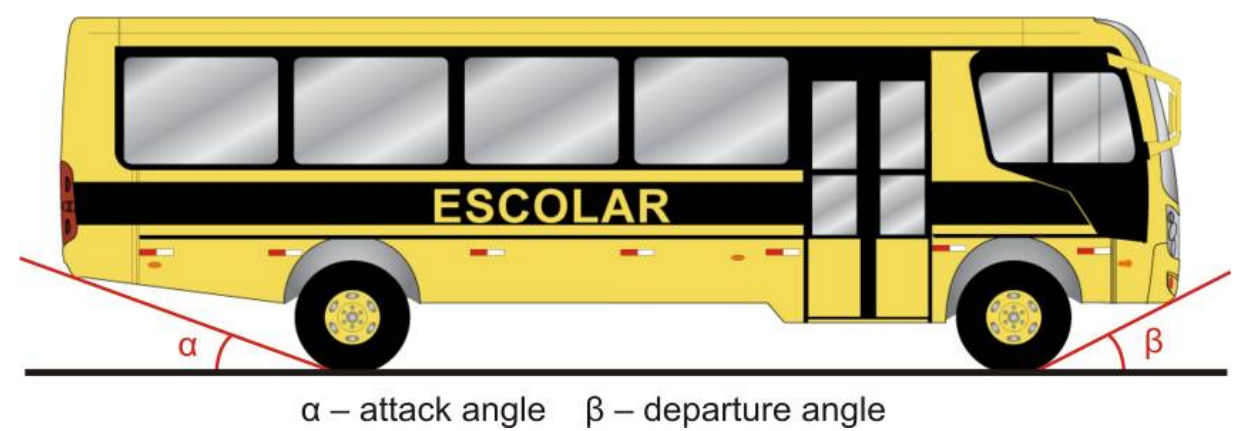

Fig. 7 Attack and Departure angles [14].

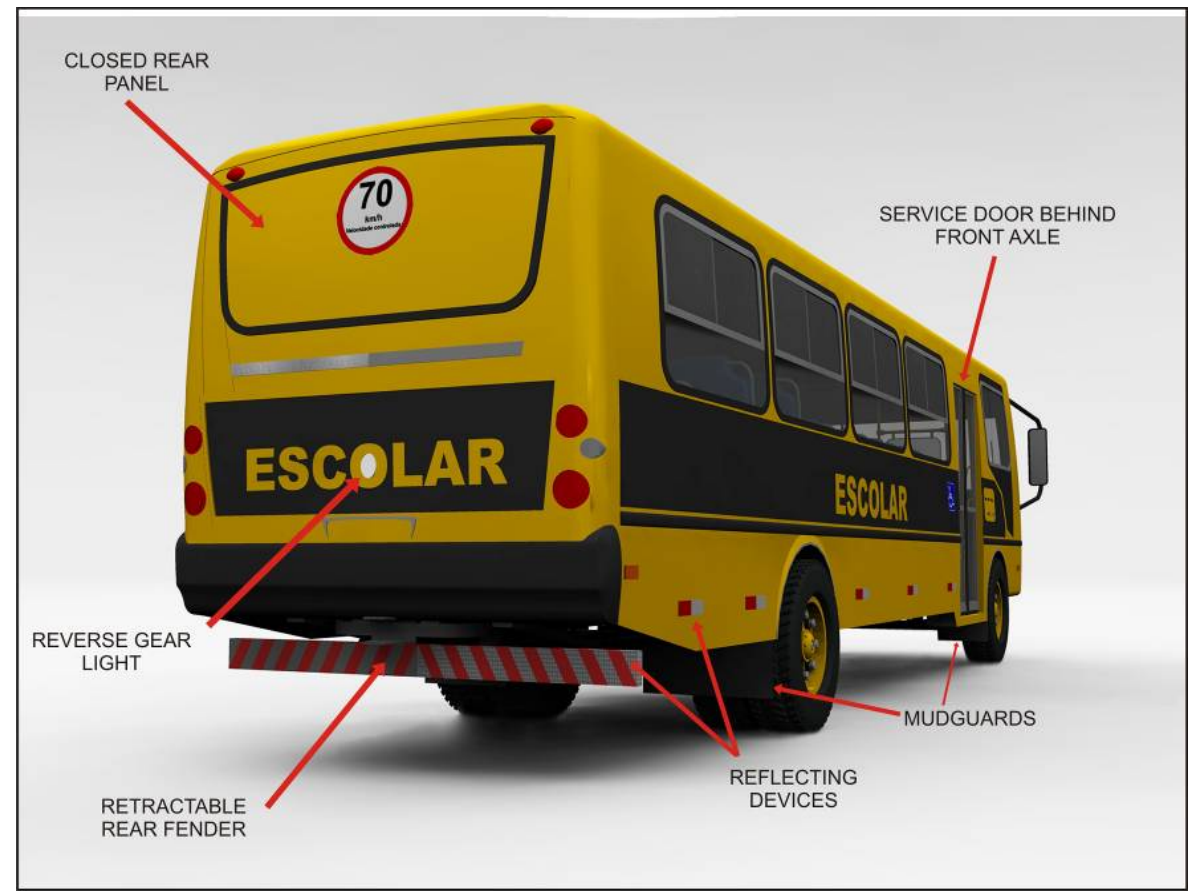

Fig. 8 Altered features of the ORE 2009 [14]. 


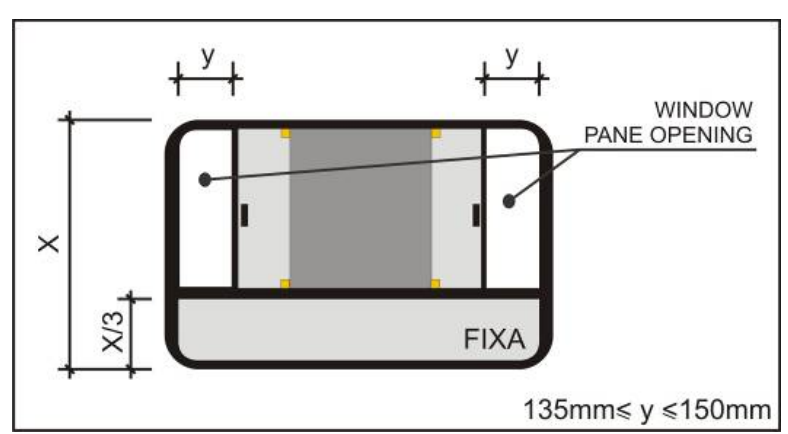

Fig. 9 Side window design [14].

Different items are needed for different categories of passenger. In the case of School Transport, some of the items are formally demanded by the provisions of the Brazilian Transport Code [7] and others by the technical norms set out in NBR 15.570 [4] and Resolution $n^{\circ} 316$ of the National Transit Council Contran [8]. The last two documents refer to collective passenger transport in general.

One mandatory piece of on-board equipment is the electronic instantaneous velocity recorder known as a tachograph. It is usually associated to GPS equipment to ensure better control of the vehicle especially in regard to speed.

The internal furnishings that make up the MAE-E on an ORE 2009 vehicle are the bench-type seats, the central aisle between the seats and a baggage rack. The seats must have a high headrest and it, like the rest of the bench, must be upholstered and covered in washable, non-slip vinyl.

The seats are all equipped with sub-abdominal seat belts. The preferential-use seat reserved for passengers with mobility handicaps or deficiency is furnished with a third support point in a diagonal position.

7.3.1 The Rural School Bus - A Vehicle Tested in The Rural Environment

There is abundant evidence of the precariousness and inadequacy of the majority of the vehicles being used to transport students and schoolchildren living in rural areas as well as the great diversity of obstacles that such vehicles have to face in the daily task of transporting schoolchildren to school and back.
The results obtained with the new model have been positive in regard to comfort, ease of driving, safety and operational performance. In regard to the technical aspects, it was found that the positioning of the front and back axles, the distance between axles and the height of the chassis from the ground are fundamental elements in guaranteeing the operational quality and drivability of the vehicle over irregularly surfaced roads and also endow the vehicle with greater stability and a more comfortable ride.

The more powerful engine installed ensures that the vehicle can get up steep slopes and ramps and perform better on roads with irregular courses where there are liable to be obstacles like mud patches, sandy patches and wet stretches.

The data obtained by the survey mentioned above show that vehicles with dimensions that are too small and engines that are not powerful enough do not meet the needs of the many municipalities where the local roads are in the worst possible conditions.

Finally, the ready acceptance and approval of the vehicle on the part of residents, drivers, students and administrators in all the municipalities that were visited was notable. That receptiveness is not only due to the safety and comfort offered by the new model but primarily because of its ability to face up to, and CENTRAL AISLE WITH REDUCED WIDTH

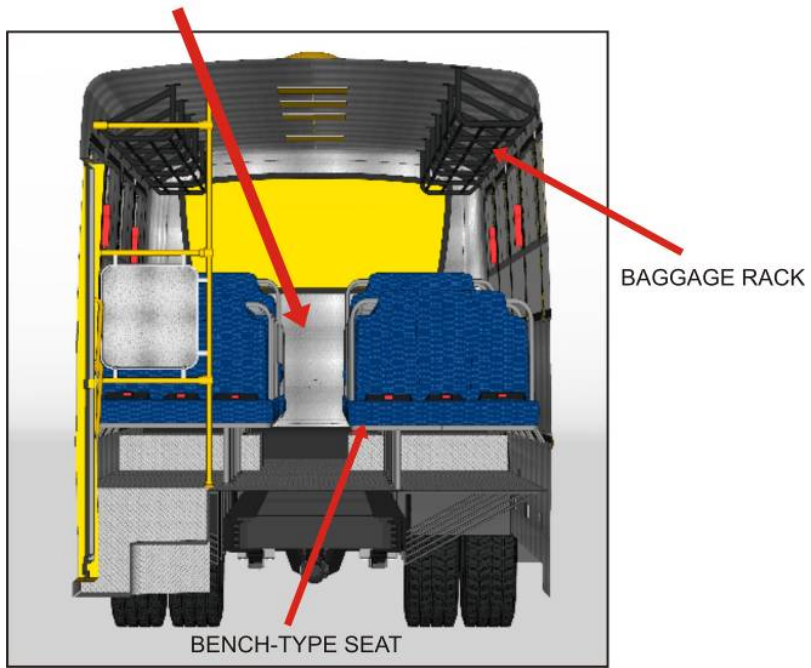

Fig. 10 Furnishings of the ORE 2009 (Ceftru, 2009). 


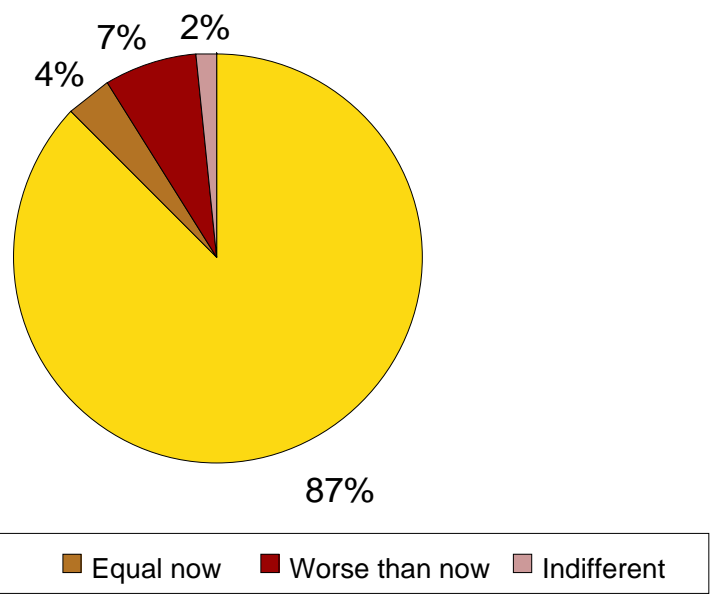

Fig. 11 Answer the question: What is your general opinion about the bus?.

overcome the obstacles that conventional buses, originally designed for city operations cannot handle. Furthermore, the ORE 2009 managed to perform over routes that up until then had only been transited by utility cargo vehicles and that indicates the possibility of finally abandoning the paradigm of Rural School Transport being conducted by the notorious "Paus-de-arara", which up until recently were the vehicles most frequently used for rural school transportation.

In the Ceftru [14] research the views of drivers who operated the transport of students in rural areas in municipalities of different states has been collected, from the extreme south to the Amazon Region, about the ORE 2009 in comparison to the local vehicles that they operate. The Fig. 11 shows that the tested vehicle best attend the needs of these operators, and $87 \%$ of drivers rated the ORE 2009 rather than the vehicles used in the operation now.

\section{Final Considerations}

Once the current configuration of Passenger Transport in Brazil has been clearly understood and the need for changes to ensure that the demands of all its users are addressed is clearly perceived, then the first step has been taken towards redressing the situation. With the appearance of the Rural School Bus, Brazil now has an adequate vehicle for operating in a rural environment.

What is needed now is to create a new classification system for the bus models being offered on the Brazilian market; one that takes into account not only the type of service to be operated, but the specificities of the environment in which services will be provided and includes the category of rural vehicle suitable for transporting workers and schoolchildren in rural areas.

In addition to that classification system there are other interventions that need to be implemented. First of all, the norms and regulatory and legal frameworks need to be updated and directives established in them to govern the manufacture of rural vehicles. Following that action, the various spheres of government and administration of the Brazilian federation need to shoulder their responsibilities in regard to passenger transportation.

In regard to rural transport services in particular, planning the operation of services, adequate maintenance of secondary local roads in the rural areas, providing ongoing capacity building for service operators, together with educational campaigns directed at rural communities are some of the more important interventions that need to be carried out to ensure that rural transport may finally become a means of social inclusion for those that dwell in the countryside. 


\section{References}

[1] R. Abramovay, Funções e medidas da ruralidade no desenvolvimento contemporâneo texto para discussão $\mathrm{N}^{\circ}$ 702, Rio de Janeiro, IPEA, 2000.

[2] ANTT - Agência Nacional de Transportes Terrestres, Anuário Estatístico 2008 (Ano Base 2007), Transporte coletivo rodoviário interestadual e internacional de passageiros, 2008, available online at: http://www.antt.gov.br/passageiro/anuarios/anuario2008/ default.asp.

[3] C. M. de Araújo, Especificação de ônibus. Consultoria Monteverde, Santos, São Paulo, 2008.

[4] Associação Brasileira De Normas Técnicas, NBR 15570: Transporte - Especificações técnicas para fabricação de veículos de características urbanas para transporte coletivo de passageiros. Rio de Janeiro, 2008.

[5] R. Blume, Território e Ruralidade: A desmistificação do fim do rural. Dissertação de Mestrado, Porto Alegre. Universidade Federal do Rio Grande do Sul, 2004.

[6] BRASIL, Constituição da República Federativa do Brasil. Brasília, DF: Senado. Diário Oficial da República Federativa do Brasil, Brasília, 5 de out de 1988.

[7] BRASIL, Código de Trânsito Brasileiro. Lei no 9.503 de 23 de setembro de 1997, available online at: http://www.senado.gov.br/web/codigos/transito/httoc.htm.

[8] BRASIL, Conselho Nacional de Transito (CONTRAN), Resolução 316 de 08 de maio de 2009. Estabelece os requisitos de segurança para veículos de transporte coletivo de passageiros M2 e M3 (tipos microônibus e ônibus) de fabricação nacional e estrangeira, available online at: http://www.denatran.gov.br/resolucoes.htm.

[9] M. L. Calandro and S. H. Campos, Ônibus: Um Segmento Industrial em Expansão. Indicadores Econômicos Fundação de Economia e Estatística, Porto Alegre 31 (3) (2003) 189 - 206.

[10] Centro De Formação De Recursos Humanos Em Transportes - CEFTRU/UNB, Projeto Transporte Escolar Rural: Instrumentos de Coleta vol.III. Brasília: Ceftru/UnB e FNDE/MEC, 2006.

[11] Centro De Formação De Recursos Humanos Em Transportes - CEFTRU/UNB, Projeto: Transporte Escolar Rural. Questionário WEB, v. II. Brasília, 2007a, p. 32 (Research Report).

[12] Centro De Formação De Recursos Humanos Em Transportes - CEFTRU/UNB, Projeto: Transporte Escolar Rural, Caracterização do Transporte Escolar nos Municípios Visitados, v. III, t. I. Brasília, 2007b, p. 261 (Research Report).

[13] Centro De Formação De Recursos Humanos Em Transportes - CEFTRU/UNB, Projeto: Transporte Escolar Rural. Sistemas de Categorias-Síntese:
Diagramas das Percepções dos Atores Envolvidos no TER, v. III, t. II. Brasília, 2007c, p. 50 (Research Report).

[14] Centro De Formação De Recursos Humanos Em Transportes - CEFTRU/UNB, Projeto: Transporte Escolar Rural. Pesquisa Ônibus Rural Escolar do Brasil. Brasília, 2009, p. 196 (Research Report).

[15] A. L. Cerra and J. L. Maia, As Atividades de Desenvolvimento de Produtos de três Montadoras de Motores para Automóveis - Estudos de Caso no Setor Automobilístico Brasileiro Revista Gestão Industrial Universidade Tecnológica Federal do Paraná, Ponta Grossa 2 (1) (2006) 1-12.

[16] A. L. Cerra and J. L. Maia, Desenvolvimento de Produtos no Contexto das Cadeias de Suprimentos do Setor Automobilístico Revista de administração Contemporânea/Associação Nacional dos Programas de Pós-Graduação em Administração, Curitiba 12 (1) (2008) $155-176$.

[17] K. B. Clark and T. Fujimoto, Product Development Performance: Strategy, Organization and Management in the World Auto Industry, Boston: Harvard Business School Press, 1991.

[18] CMTC, Tróleibus: veículo de dois eixos, especificações técnicas, Companhia Municipal de Transportes Coletivos - CMTC, São Paulo, 1985.

[19] F. L. Consoni and R. Q. Carvalho, Desenvolvimento de Produtos na Indústria Automobilística Brasileira: Perspectivas e Obstáculos para a Capacitação Local Revista de administração Contemporânea/Associação Nacional dos Programas de Pós-Graduação em Administração, Curitiba 6 (1) (2002) 39-61.

[20] A. M. C. Dias, Produto Mundial, Engenharia Brasileira: Intergração de Subsidiárias no Desenvolvimento de Produtos Globais na Indústria Automobilística. Tese de Doutorado, São Paulo, Universidade de São Paulo, 2003.

[21] FABUS - Associação Nacional dos Fabricantes de Ônibus, Modelos de ônibus, available online at: http://www.fabus.com.br.

[22] A. C. P. Ferraz and I. G. E. Torres, Transporte Público Urbano, Segunda edição, ampliada e atualizada, Editora Rima, São Carlos, 2004.

[23] Fundação Getúlio Vargas/Centro De Políticas Sociais (FGV/CPS), Motivos da evasão escolar. Rio de Janeiro: FGV/IBRE/CPS, 2009, available online at: http://www.fgv.br/cps/tpemotivos.

[24] Fundo Nacional De Desenvolivmento Da Educação FNDE, available online at: http://www.fnde.gov.br/index.php/programas-caminho-da -escola.

[25] M. L. B. S. Galindo, et al. Mobiliário, Acessórios e Equipamentos Embarcados (MAE-E) - Conceituação e Especificação dos itens necessários para caracterização 
de um veículo para o Transporte Escolar. In: CONGRESSO DE PESQUISA E ENSINO EM TRANSPORTES, 23, 2009, Vitória, ES.

[26] Instituto Brasileiro De Geografia E Estatística (IBGE), Sinopse do Censo Demográfico 2000, Rio de Janeiro, 2001.

[27] Instituto Nacional De Estudos E Pesquisas Educacionais (INEP/MEC), Censo Escolar 2009, available online at: http://www.inep.gov.br/basica/censo/.

[28] J. S. C. Maciel and M. S. Santos, Diagnóstico ambiental de estradas vicinais na Amazônia, in: CONGRESSO DE PESQUISA E ENSINO EM TRANSPORTES, 2007, Rio de Janeiro, RJ.

[29] M. Mariotoni, Rodovias Vicinais: Conceituação e Importância. Dissertação Mestrado, Escola Politécnica, Universidade de São Paulo, São Paulo, 1987.

[30] H. P. Nascimento et al., Caracterização do ônibus para operação do transporte escolar rural no Brasil, ANPET, Rio de Janeiro, 2008.

[31] NTU - Associação Nacional das Empresas de Transportes Urbanos, Anuário 2008/2009, available online at: http://www.ntu.org.br/novosite/arquivos/ anuarioNTU2008-2009-web.pdf.

[32] T. V. L. Nunes, Método de previsão de defeitos em estradas vicinais de terra com base no uso das redes neurais artificiais: trecho de Aquiraz - CE. Dissertação Mestrado. Mestrado em Engenharia de Transportes. Universidade Federal do Ceará. Fortaleza, 2003.

[33] D. S. Reis, O rural e o Urbano no Brasil. Caderno de Geografia, Belo Horizonte 15 (25) (2005) 77-92.

[34] I. F. Santos, Transporte e eqüidade no acesso à escola: um estudo de caso da unidade de ensino do Cefet-Pln em Alagoas. Masters dissertation, UFPE, Recife, 2005.

[35] E. A. Vasconcellos, Transporte urbano nos países em desenvolvimento: reflexões e propostas. Annablume, São Paulo, 2000.

[36] J. E. Veiga, A relação rural/urbano no desenvolvimento regional, In: Botelho Filho, F. B. Agricultura familiar e desenvolvimento territorial - contribuições ao debate. Brasília, DF, Universidade de Brasília, 2005, pp. 9-22. 